\title{
Queer Fire: Ecology, Combustion and Pyrosexual Desire
}

Nigel Clark and Kathryn Yusoff

\section{Introduction: Ecology at the Limit}

The scale and complexity of climate change present challenges when it comes to depicting the current planetary predicament in ways that will appeal - starkly, immediately, viscerally - to non-expert audiences. Drought is painfully drawn out, extinction's disappearances resist graphic depiction, and too few of us empathise closely with the chilly realms of retreating ice...

But there is always fire to fall back on. Wildfire moves with eye-catching speed, it rages with dramatic intensity, its energetic excitations light up the screen. Fire brings it home. We've all seen what an out-of-control blaze does to a room, a house, a community - and felt, if for a moment, the punishment flame exacts on exposed flesh. Fire turns verdant life into choking clouds and deathly ash. And burning vegetation, informed audiences now know, pumps carbon into an atmosphere already flush with greenhouse gas emissions.

That many of us have come to see fire as loss rather than renewal, destruction rather creation, is bound at once to western ideas of ecology and economy. From the $18^{\text {th }}$ century naturalist Gilbert White's observation that 'nature is a great economist' (Worster, 1985, p. 9), through to the 1972 Blueprint for Survival's affirmation of 'the essential cyclic nature of all ecological processes and the absolute necessity for recycling everything' (1972, p. 71), the otherwise contrary fields of ecological and economic thought have 
frequently mirrored each other's abhorrence of inefficiency and waste. Nowhere has this shared disdain been more acute than in the condemnation of uncontained, free-burning fire.

Constantly fearful of the use of fire in urban uprisings - the metropolitan elites of a modernizing Europe saw open fire as an affront to reason and order, just as they viewed the other unruly energies of the masses with trepidation (see Marder, 2015, Ch. 3). It's no coincidence that the idea of a curfew to regulate the movements of urban bodies derives from couvre feu — the covering or extinguishing of fire (Pyne, 2001, p. 109). Exporting their pyrophobia from city to country, enlightenment agronomists came to see fire in forest or field not only as a form of disorder but as the squandering of organic wealth that ought to be put to productive use (Pyne, 1997a, pp. 162-9).

As a means to tighten and amplify the circulation of vital energies, suppression of the urge to burn has often been accompanied by regulation of other bodily desires. Along with an abiding suspicion of fire, we suggest, it is the anxiety about sex and procreation in much ecological thinking that points to its complicities with the powerknowledge relations of a modernizing Europe. We are far from alone in divining continuities between otherwise ‘radical' ecological imaginaries and more orthodox modes of modern thought and practice. Such misgivings resound through a throng of ecological 'heterodoxies’ that include feminist, queer, indigenous, postcolonial, poststructural, Marxist, anarchist and animal liberationist positions - and their many crossfertilizations. Fervently 'ecological' in their own ways, these approaches often find themselves, or construct themselves, in opposition to some of the precepts and axioms of more ‘mainstream' environmentalism - a field that is itself by no means singular or unitary. 
Our own wish to ignite some thinking around sex and fire is a response not so much to the presence of limits in more 'orthodox’ environmentalisms, but to a pervading assumption that the best way to deal with limitation is through greater economy, parsimony, self-moderation. Though not quite as easy to demonize as wildfire, we note that unregulated human reproduction has also been taken as a threat to the essential cyclicality favoured by the ecological imagination - an observation that inherits earlier insights at the intersection of queer, feminist and ecological thought. As Catriona Sandilands observed some time ago, 'one of the most disturbing sites of "self-limiting' ecological wisdom lies in discourses around population', or as she puts it more bluntly 'limits to sex' (1999, p. 81). And as Sandilands discerns, coming down on the side of curbing desire, renouncing pleasure and policing 'expenditure' is not simply a matter of disgruntling feminist or queer critics - it may well be one of the most significant impediments to the broad appeal of ecology as a social movement.

In critical social thought the usual response to talk of limits - ecological or otherwise - is to insist that all boundaries are socio-culturally or discursively constructed rather than 'natural'. Consequently if neither our desires nor the point at which desirous behaviour crosses over into excessiveness are dictated by nature, it is up to us to collectively decide how, where and when to express ourselves - and to actively oppose any authority who would deny us this right and this responsibility. But is this the last word on the play or the negotiation of desire? For there are other ways of conceiving of desire that would see any such socialization of limits and excess as itself a kind of circumscription or containment. Other approaches, that is, which have asked what it might mean if our excitations, our incitements to desire, lay in some part beyond the social. Or even beyond the earth itself. And with such an opening - the imagining of an 'ecology' or an 'economy' that is not restricted to our own world - come some interesting questions on what we might do with fire and sex. 
The second corollary of releasing desire into the cosmic or incorporeal realm is to engage with questions of reproduction via fire. As a mode of reproduction that is decidedly nonnormative and breaches the impasse between sexual and asexual reproduction, fire provides a material register and figure for queer theory that 'jumps' questions of inheritance to initiate new genealogical configurations. As a 'queer' reproductive logic that regenerates prodigiously without recourse to sexual or species reproduction, fire models genealogies that are both exuberant and future-orientated - to offer another kind of reproductive futurism which is not grounded in those logics of patriarchy, family or progeny that remain decidedly intra-species and intra-planetary. Structurally, fire licks the boundary between biologic life and inhuman materialities ${ }^{1}$, offering a pyro-evolutionary tack that substantially restructures the asexual-sexual binary with lateral forms of agency and modes of intensification (or desire). Rescripting ideas of ancestrality beyond the logics of reproductive futurism that are so firmly secreted in biologisms (and its tying together of reproduction and forms of productivity), fire queers the pitch of sex with excessive pyroerotic potentialities and untimely temporalities.

Extrapolating on Nietzsche's notion of a sun that pours out its radiance endlessly and without expectation of return, Georges Bataille forged an entire `social' theory around the idea that the prime challenge of earthly existence is how to deal with an excess of incoming solar energy. But for Bataille, the very idea of 'excess' is coupled with a conception of limits - for it is the bounded sphericality of our planet that ultimately imposes a limitation on the expansion of life, a threshold that no amount of discursive or political wrangling will evade (2013; 1991, pp. 20-3). Bonded to a finite astronomical body, we and other creatures have no option but to expend the superfluity of energy available to us. For Bataille, sexual activity that is geared to reproduction sooner or later comes up against these terrestrial limits - as does economic activity that cycles 
consumption into more production. But sex for its own sake, sex for the pleasure of it just like any off-loading of economic goods that manages to escape the circuit of reinvestment - is pure discharge, non-productive expenditure, a waste of energy (Bataille, 2013, p. 35; 1991, p. 181).

It is more than just the breaching of cyclicality in the thought of Bataille and his heirs that offends ecological sensibilities. As historian Anna Bramwell has noted, it is above all 'the fear of irrevocable loss that characterises the ecologist' (1989, p. 97). And facing up to unsublatable loss is what Bataille does best. For while he may aspire to prolonging the free gifts of the sun in as generous and benevolent ways as possible, Bataille acknowledges that this is only a temporary solution - and that ultimately the fate of everything on earth and in the cosmos is pointless destruction, or 'pure loss' (2013, p.35; 1991, p. 181). It is this intuition, he adds, that underpins `Our desire to consume, to annihilate, to make a bonfire of our resources, and the joy we find in the burning' (1986, p. 185). Until recently, this 'pure loss' has been cul-de-sacked in the repository of geologic time, neatly separated from the productive lifeworlds of biology.

While Bataille deserves credit for envisioning both sex and fire as expressions of an exorbitant energy flow, his sexual scenarios are clearly not to everyone's taste. We would add that like most Europeans, Bataille is stronger on fiery metaphors than he is on the practicalities of working or playing with flame. But what is intriguing about his insistence that endless acquisition without discharge results in explosive energetic buildup is the way that it resonates with a rising - if still contentious - tendency amongst fire ecologists to accept the periodic necessity of fire in most of the earth's forests, scrublands and grasslands. For an increasing number of fire researchers now concede that a world of traditional and indigenous practitioners had it right all along: this is a planet that is bound to burn, and if fire is withheld from accumulating biomass we invite deadly, 
uncontrollable conflagrations (Pyne, 1994; 1997a, p. 546; Bowman et al., 2009; Langton, 1998, p. 53). A conclusion that is not a world away from what the psychoanalytic tradition, amongst others, has said about the buildup and release of libidinal energies.

Our own thinking in this paper is shadowed by the escalating animosity - in certain quarters - over the apparent refusal of other bodies to manage their desires, to contain themselves, to stay in place. This is a set of concerns, it has been noted, which is increasingly linked to global climate change (Bettini, 2014). So too are we mindful of the claim of fire researchers that terrestrial wildfire 'appears more profusely during times of rapid and extreme climatic change' (Pyne, 1994, p. 890). But fire and sex - conceived in the broadest sense - are not simply on a collision course. To think critically and creatively through the current conjuncture, we suggest, needs a long run up, a genealogy that traces the deep, conjoint history of sexual desire and fiery consummation.

By coupling sex and fire, by contextualising the 'pyrosexual' within the wider economy of the earth and cosmos, we at once seek ways to escape industrial capitalism's current hyper-consumptive cycles of accumulation and ways around ecological thought's consternation over unmanaged desire. Putting speculative thinking about sex and reproduction in conversation with a range of ways of theorising fire, we explore how fire mediates between organismic desire and the energetic dynamics of the earth and solar system in ways that differ from biologism's attachment to a 'productive’ sex.

In the first section we take a genealogical approach to fire and sex that traces their entanglement form the initial 'assembling' of fire through to the emergence of a living being capable of manipulating flame. The second section looks at how fire has been contained and intensified by human actors, and the role that the heat-driven transformation of inorganic matter has played in the incitement and channeling of desire 
in urban spaces. The third section addresses the development of industrial 'heat engines' and the implications for desire and reproduction of tapping vast reservoirs of subterranean solar energy. We round off by considering what alternative possibilities might lie in the embroilment of sex and fire on a planet undergoing rapid change.

\section{Celestial Fertility, Green Fire}

'Light my fire', 'the fire down below', 'with sighs of fire': popular culture present and past has routinely linked sexual urges to the more elemental force of fire. But the metaphoric movement should really go in the other direction, for it is the reproductive capacity and profligacy of life - organismic desire - that is the condition of possibility of fire. With our fidgety, fire-wielding hands and our unseasonable passions, we hominids may burn with desire, but it is fire itself that is pyrosexual - all the way down.

As environmental historian and pyrogeographer Stephen Pyne insists, we live on `a uniquely fire planet' (1994, p. 889). Ours is the only astronomical body in the solar system that routinely burns, Pyne adds - with the proviso that fire is a relatively late arrival on earth. Fire requires an ignition source, an oxygen-rich atmosphere and a stock of fuel. Lightning was most likely present on the primordial earth. Early photosynthesizing microorganisms - mostly marine-based, tipped the earth's atmosphere into an oxygenated state over 2 billion years. But it wasn't until the colonization of the continents by tall-stemmed, tough-bodied plants some 400 million years ago that the fire assemblage came together (Pyne, 1997a, pp.16-17; Scott, 2009, p. 24). And this is a genesis that takes fire's sexual and reproductive associations into realms that radically exceed the individuated bodies and binary couplings within which most mainstream culture imagines that desire does its burning. 
Fire - more strictly, combustion - is a chemical reaction in which energy held in the atomic bonds of a fuel is released through oxidation — a reaction with oxygen or an oxygen-rich compound-leading to the release of heat and the formation of new chemical bonds. In short, fire unravels what photosynthesis has brought together, as does the metabolic process through which animal cells convert nutrients into energy (Pyne, 2015, unpag.). But first, plants must capture and process the radiant energy of the sun into the chemical energy of living tissue, they must tap into what Bataille refers to ‘celestial fertility’ (1985, p. 8). In the words of biologist Lynn Margulis and science writer Dorian Sagan: `Burning like a cool green fire, photosynthetic beings transmute sunlight into themselves' (1995, p. 158). The earliest clear evidence of the ability to metabolize solar energy goes back some two and half billion years - though it is probably much older, with single-celled and colony-forming cyanobacteria first introducing photosynthesis onto dry land some 1,200 million years later.

As endosymbiotic theory ${ }^{2}$ has it, neither binary sex nor propagation by cell division was enough to have gifted plants the ability to turn sunlight into living tissue (Margulis and Sagan, 1995, p. 159). There is now a body of evidence indicating that plants acquired the ability to photosynthesize when certain of their component cells engulfed but failed to digest cyanobacteria, the surviving blue-green bacteria enduring as choloroplasts - the tiny light-converting structures within host plant cells (Raven and Allen, 2003). Building on this metabolic foundation, it took a great deal of plant sex and some evolutionary twists and turns to populate the terrestrial world with fully combustible vegetation. As Margulis and Sagan remind us `Plants are sexual beings. Sexual coupling is the act, and the embryo is the structure, that distinguishes them from algae and other phyla that have sometimes been misrepresented as "plants" (1995, p. 164). Plants proper have a complex reproductive strategy comprising a stage at which spores are produced by cell 
division and second phase involving fusion of male pollen or sperm with female plants or female parts of hermaphroditic plants.

But terrestrial plant life also needed to stretch back towards the sun if the spark of lightning was to find fuel to ignite. Gradually, plants acquired the stems or trunks that allowed them to stand upright, they developed vascular or conducting tissues to move water, minerals and photosynthetic products around their extending bodies, and they evolved cell walls stiffened by the organic polymer lignin - otherwise known as woodwhich provided structural support. Literally branching out, vascular plants `came to enshrub and enforest the world' (Margulis and Sagan, 1995, p. 169). And in the process they enflamed that world. Though their fortunes ebbed and flowed with changing climatic conditions and fluctuating atmospheric oxygen concentrations, fire and vegetation from this point on were fused in a mutually transformative encounter. As plant sex spawned new generations of plants, it also made new fire. As plant life mobilized, evolved and radiated, so fire migrated, proliferated and diversified. As plants made the living world more hospitable to flame, so too did wildfire select for species or communities that tolerated, even depended upon, flame (Pyne, 2001, pp. 10-15; 1994, p. 890).

Fire can be deferred, fire ecologists and pyrogeographers increasingly insist, but it cannot be abolished, any more than plant reproduction can be prohibited. If leaf-litter and other biotic matter builds up, it will it sooner or later attract an igniting spark (Pyne, 1997b, pp. 252-3). As Bataille and his fire science counterparts agree, if life cannot grow or expand indefinitely, it must eventually expend itself - or go out in a blaze of glory. The wider lesson being that the most or the best any organism can do is to prolong, for a time, the gratuitous, irrecompensible offerings of the sun. In Bataille's words, 'to live signifies for you not only the flux and fleeting play of light which are united in you, but the passage of 
warmth and light from one being to another' (1988, p. 94). And perhaps no being does this with more passion, more fervour, than the fire-adapted plant. As geographer Lauren Rickards elaborates:

Fire adapted plants make the ultimate parental sacrifice, filling themselves with oils in order to ignite the life cycle of their young. Once disintegrated through combustion, these plants do everything they can to nurture their offspring, waking them from their slumber with complex chemical signals, gifting them with an abundance of nutrients, sheltering them in a warm bed of ash, and stepping aside to allow them their time in the sun (2013, unpag.)

This imbroglio of fire and life, however, is always more than is strictly needed for survival. Indeed, we might see it as a tryst that breeds excess and exuberance. After a few hundred millions years of fire-accelerated evolution, plant life irrupted into flowering and fruiting varieties. With a keen sense of both the solar origin of life and the throes of organismic desire, Margulis and Sagan depict the arrival of angiosperms as a multisensory, cross-kingdom enticement to animals to aid them in the work of fertilization. 'Green fire', they proclaim, 'converts wildly to the red and orange and yellow and purples of sexual fire of flowering plants' (1995, p. 175).

Among the animals that succumbed to the allure of flowering, fruiting plants was a genus that learned to handle flame - the emergence of a fire creature being an inessential but perhaps unsurprising product of an endemically fiery planet (Clark and Yusoff, 2014, pp. 223-4; Pyne, 1994, p. 889). With the capture and propagation of fire a million or more years ago, hominids become part of the sexual apparatus of the plant kingdom, their torch-wielding tendencies accelerating the selection and diversification of fire-adapted plants, including the plants to which they were attracted (Margulis and Sagan, 1995, p. 
171). In this way, as Margulis and Sagan observe in conversation with Bataille, both human sexual desire and human intelligence -like that of all our animal kin - is ultimately a product of photosynthetic green fire, itself a prolongation and channeling of solar excess (Margulis and Sagan, 1995: pp. 164, 175; Bataille, 1986, p. 100).

For philosopher Elizabeth Grosz, the scents, shapes and colours of plants and the desirous behavior of sexual beings are examples of a natural exuberance that exceeds the dictates of survival. This excess, for her, is what defines art. 'Art', writes Grosz, 'is where the becomings of the earth couple with the becomings of life to produce intensities and sensations that in themselves summon up a new kind of life' (2008, p. 79). And it is the pleasure of sexualization that is the prime means by which living organisms draw out and expand upon inorganic or earthly potential: 'Art is the sexualization of survival, or equally, sexuality is the rendering artistic, the exploration of the excessiveness, of nature' (Grosz, 2008, p. 11). While it is not a theme Grosz herself develops, we would see fire as one of the most vital and effusive ways that that the generative potential of the organic and the inorganic meet and join forces, a preeminent means by which living things ‘contact and cross-fertilize the earth’ (Grosz, 2008, p. 20). Indeed, if the earth has its own art forms, then the flame that irrupts where sex and solar energy join forces is surely one of its most splendid productions.

An understanding of the implication of fire and biological life, we suggest, does two things for our thinking through and about sex. First, it helps us to see that earthly forces which are often assumed to be more basal or 'elemental' than life processes may turn out to be much more entangled with the biological - and with life's constitutive sexual and asexual desires - than we previously imagined. Second, the focus on fire helps bring into relief the complex, variegated sexual and asexual geneses of plant-life that are the condition of possibility of our own ‘animal' existence. Bringing these two points 
together foregrounds the literally world-shaping power of sexualities that are far from the heteronormativities and filial modes of inheritance prevalent in contemporary 'green' thought. In this way, the idea of an originary pyrosexuality draws our attention to differential forces at the juncture of organismic life and the non-living earth. Appreciating that these 'primordial' forces remain vibrant, open and unfinished - we propose - is a step towards the material and imaginative rescripting of environmental futurism.

The hominids who began tending fire could not have anticipated most of its effects on ecosystems and life-forms (including themselves). In the light of Grosz's sense of creative elaboration on the earth's expressiveness, we might speculate that the first wielding of a flaming branch was no more or less than a gesture, a dance, a rhythmic extension of wildfire's own glorious display. While landscape burning developed into both a rigorous discipline and an artful celebration, this was by no means the culmination of human fire play. For the fire creature was also to learn how fire could be extracted from its natural milieu - how it could be contained and magnified. In this way, humans engendered forms of beauty and utility that rivaled even the sensuous productions of the flowering plants, intensifying the already intense materiality within the logics of a profligate lineage. And in the process of bringing new fiery arts and novel fired objects into being, they also transformed the fabric of their lived existence - and the very contours of their sensual and sexual relations.

In the following section we turn to the city building and urbanism that has been increasingly central to human existence over the last nine or ten millennia - which is to say, throughout much of the epoch geologists refer to as the Holocene. Extrapolating on philosopher Claire Colebrook's suggestion that there is a fundamental sexual dimension to city life, we propose that working with fire - the practice of 'pyrotechnology' and all 
its products - plays a vital role in the meditation and amplification of urban sexuality.

\section{Pyrotechnics of Desire}

If different human groups, over hundreds of thousands of years, learned how flame could transform their living environment, they also gleaned that fire transmuted other matter. Just as flame softened flesh, so too could it harden a wooden spear tip, bake mud or clay, crack the very rock underfoot (Pyne, 1997a, p. 41). Beginning perhaps as a way to shelter flame from inclement weather (Fernández-Galiano, 2000, p. 5), the containment of fire in purpose-built structures also served to focus and intensify its force. "Revealingly the etymology of the English word "focus" derives from the Latin focus, meaning "'hearth"' notes Pyne (1994, p. 889). But so too has the hearth long been indicted as the focal point of women's social and sexual oppression, the crucible of their exclusion from public life and confinement to domestic roles and spaces (see Morgan, 1977).

In this sense, the hearth intensifies a gendered division of labour that has been linked to the domestication of fire (Wrangham 2009, p. 130). As Pyne ominously observes: 'Someone had to gather the endless fuel, someone had to fuss over the flames and nurture the coals, and someone had to oversee its proper use (2001, p. 24), though taking on the fire-tending role seems by no means to have excluded women from participation in open field burning. But even once the hearth-bound flame is firmly established, there are other ways we might conceive of the libidinal possibilities that attended the containment and intensification of fire.

The earliest known purpose-built chambers for fire are the kilns uncovered at the Dolní Věstonice and Pavlov sites in what is now the Czech Republic. Here, along with many 
sculpted and fired animal forms, a number of the now-famous voluptuous 'Venus' figurines have been unearthed. These artefacts and the kilns in which they were fired have been dated at around 25,000 BP, which locates them deep in the last Pleistocene Ice Age (Vandiver et al., 1989). What we might expect of a tiny cluster of settlements a stone's throw from the great northern ice sheets is the husbanding of fire and fuel for the rigours of daily survival. Yet excavations reveal no trace of earthenware vessels, no fired object of any discernible utility. Mixed up with the more celebrated 'finished works' are pellets, tubules, pinchings, amorphous shapes and incomplete figures-a profusion of fragments amounting to over 10,000 distinct pieces. Given the clear indicators of ceramic skill, archaeologists speculate that this superabundant trove is less an archive of failed or evolving competence than the signs of a creativity that was overwhelmingly performative, evidence that the very act of partaking in the fiery transmutation of earthy matter was valued over and above its substantive outputs (Vandiver et al., 1989, pp. 10078). Or we might say, in Grosz's terms, that this was contact with and cross-fertilization of the earth.

The containment and 'focusing' of fire - in the oven, the kiln, the furnace - may well be one of the most momentous turns of the coupling of fire and life since a primate genus captured fire. The absence of male figurines or anything approximating phallic forms at Dolní Věstonice, together with the well-documented association of early pottery with the ‘female domain of hearth-centred activities’ (Haaland, 2007/8, p. 101) suggests creativity of and by women. Keeping in mind that ancient artisans generally constructed their own apparatuses, this would make it likely that the enclosure of fire was a female invention. Or rather, a moment in the invention of what we have come to understand as the female subject. 
With waning of the last of the Pleistocene glaciations and the rise of agriculture and sedentary life, the purpose-built fire chamber proliferates (Clarkand Yusoff, 2014). Not only vital for rendering seeds and grains digestible, the oven's fiery interior also brings forth the earthenware vessels in which cultivated foodstuffs are stored, prepared, served. At some point, archaeometallurgists surmise, the use of ores as pottery glazes must have dribbled enough shiny residue to have sparked an interest in the smelting of metals (Aitchison 1960, p. 40). Though metallurgy becomes as unambiguous a male domain as early pottery is female (Haaland, 2007/8, p. 101), commentators have insisted that pyrotechnology - the use of high heat to transform the properties of inorganic matter is best seen as a continuous and integrated field (Wertime, 1973, p. 676).

Eventually the outputs of the fiery furnace - ceramics, plaster, cement, metal, glass, concrete - come to compose the very fabric of urban life. But even though pyrotechnic products will find legion uses across the ancient world, the 'gratuitous' creative urges attributed to the ceramicists of Dolní Věstonice never quite recede. Theorists of high heat technology draw attention to the fact that artistic, decorative and voluptuary expressions of pyrotechnology precede any instrumental use, and that the decisive breakthroughs most likely emerged in spirit of playfulness and open-ended experimentation - through `a rich and varied sensual experience of the kind that comes directly from play with minerals, fire, and colors' (Smith, 1981, p. 203).

As Grosz would have it, faced with the chaotic immensity of earth and cosmos, it is necessary to scale down, to bracket off intimate spaces so that potentially destructive physical forces might be more or less safely turned to the task of creative experimentation (2011, p. 38). Like the chloroplasts that enfold and reprocess the force of solar energy, the kiln captures and enchambers the blazing power of wildfire, ratcheting up temperatures to the point where they can do the work of the planet's own 
molten interior (Clark, 2015; 2017). With heat that reaches volcanic intensity, artisans coax from their fiery furnaces forms, compounds, embellishments as yet unrealised by the earth itself. In the process, with impacts they could no more have anticipated than those of earliest fire-using hominids, ancient pyrotechnologists unleashed a parade of novel objects and geochemical recombinations. Even the chroniclers of pyrotechnical innovation - mostly men who are themselves technically proficient in the gritty, grimy process of heat induced transmutation - seem to wax tender and sensual at the thought of such novel enchantments leaving the kiln and setting out into the wider world. 'All big things grow from little things’, muses metallurgist and mineral scientist Cyril Smith, `but new little things will be destroyed by their environment unless they are cherished for reasons more like love than purpose' (1981, p. 331).

Rather than simply pointing up the uneven ways that women and men were impacted by this stream of new things, we would suggest that in changing the mineral or geologic composition of every day life, pyrotechnology helped recompose social and sexual subjectivities (see Yusoff, 2013 pp. 780-1; 2015, pp. 209). In the increasingly populous urban centres of the ancient world, kiln-fired materials afforded substance and durability to the built environment. Under conditions of unprecedented social proximity, the hardbaked bricks, tiles, cements and concretes served to channel 'the movement of human flesh' keeping some bodies apart, holding others together (De Landa 1997, pp. 27-8). But as in the reproduction of biological worlds, the dance of fire and life at the core of human 'civilization' overflowed the strictures of necessity or purpose. From much the same ovens that seemed to bind some women to domestic space came artful objects and eye-catching adornments: things to see, to feel, to flaunt, to be enticed or enchanted by. If the glittering products of the artisans kiln functioned as 'visual displays of identity' that signaled where and when people belonged (Roberts et al. 2009, pp. 1019), so too did they help precipitate surges and poolings of desire that could not so easily be corralled. 
As an ecology - as a shifting imbrication of organic and inorganic forces - the city itself might be seen as a turning point, an event in the transformation and intensification of sex. As Colebrook proposes:

what makes a city a city is the intensity with which relations among bodies exceed self-interest and self-preservation (or are sexual). By the same token, a relation between two bodies is sexual (rather than bound by organic preservation) to the extent that it is urbane - oriented to differences, style, flair or display, and not to reproduction (2017, p. 40)

The pyrotechnical transmutation of earthy matter into both structures of containment and objects of enchantment, we suggest, is the molten core of this reconfiguration of sexual desire. From the ancient foundries came the shimmering stimuli of urban desire but also the implements that would increase agricultural production and direct reproduction to certain kinds of human, animal and plant bodies. If the artisanal furnace fabricated bodily ornaments that captivated the senses, so too did it forge the shackles that fettered other bodies; if it poured forth the metallic tokens that aided trade and circulation, the same glittering coinage facilitated the purchase of bodies, their labour, enslavement and sexual favours. As archaeometallurgist Theodore Wertime concludes of the metals that pyrotechnology injected into early urban existence: 'They became catalysts of social life for men even as they had been catalysts of energy exchanges for cells in the biological organism' (1973, p. 680). But so too did the arrival of metals enable the hoarding of wealth as never before - just as it furnished the weapons to amass and guard these stockpiles (Goudsblom, 1992, p. 63).

As Margulis and Sagan deftly observe `(t)he monetary economy attempts to arrest the 
solar flux of Earth's economy' (1995, p. 165). Fuelled by wood or charcoal, we are reminded, the traditional kiln is still an extension of solar excess, an elaboration on green fire, a set of variations played on the forces of earth and cosmos. Marx, incidentally but delightfully, is not far off when in the Grundrisse he cites an old Peruvian saying that Gold is the tears wept by the sun $(1973$, p. 833). If the chambered flame at the heart of urban life intensifies, enhances and extrapolates upon sexual possibility, not everything that arises out of the `creative participatory joy’ of working with fire and earthy matter extends the flow of warmth or light from one urban body to another (see Smith, 1981, p. 355). It is only too obvious that many new things, new expressions, new potentials for exploring erotic and sensual desire were not protected or apprized ‘for reasons more like love than purpose'. And as the ability to contain and intensify fire advanced, as human pyrotechnics turned for its feedstock from solar flow to fossil sunlight, so too was desire in all its permutations subjected to forces and pressures without precedent.

\section{Fossil Capital, Carboniferous Love}

The emergence of the city, Manuel De Landa proposes, can be viewed as a kind of remineralizaton of biological life: the clay and stone structures of urban built space constituting a literal re-enfolding of the geologic into the world of the (human) organism (1997, p. 25-8). We would extend this argument to include the many ores and minerals that the pyrotechnic arts introduced - in transmuted form - into the fabric of urban life. To this we have been adding that the fire-forged minerality of the city serves as a conduit and catalyst of human desire. If flame helps simmer, fuse, meld and alloy the heterogeneous elements of social life into a workable unity, so too do its lustrous productions incite passions that urban socio-sexual orders struggle to contain. 
But this re-enfolding of geology into biology is even more complex, more convoluted, than it first appears. For many of the metallic ores that pass through the artisan's fiery furnace have themselves - over millions of years - been gathered and concentrated by the activities of microorganisms (Westbroek, 1983). The process of 'biomineralization' and geochemical evolution (Hazen 2010), in this sense, reminding us that even the most rigidly geologic matters may bear the trace of prolific and promiscuous organismic desire. With the turn to fossilized hydrocarbons as an energy source - a few centuries ago in Europe, earlier in China - this debt to the generativity of life deepens, expands, becomes more direct.

Coal, the first of the major hydrocarbon sources to be widely exploited, is the buried, heated, pressurized remains of ligneous or woody plants. Like its kindred fossil fuels oil mostly derived from algae, natural gas from both algae and plants (Alley, 2000, p. 170) - coal is ultimately photosynthetic, cosmic fertility converted into green fire. The major coal seams were laid down by the early, now mostly extinct, macro-organismic photosynthesizers of the Carboniferous (Freese 2006, p. 3). It has been proposed that great bulk of these deposits exist because of a time lag between plants evolving lignin and fungi learning how to decompose woody tissue (Margulis and Sagan, 1995, p. 160). Those of us privileged to partake of this exceptional bounty of mass organic fossilization, it might be added, have also enjoyed a window of opportunity. Fortuitously positioned in the interval between the opening up of the fossil fuel frontier and the closing down that will be that impelled by climate change, it might be said, we owe our brief flourishing to that earlier interlude in which the heliotropic yearnings of ancient plants took them one step ahead of fungal decomposition.

In the high-pressure domain of critical climate politics - coal, oil and gas are construed as planet-destabilizing powers that must be urgently renounced. Beset with blockages and 
deviations, the quest to overcome fossil fuel dependence understandably sets its sights on tangible shifts in attitude and behaviour. But it is also important to ask how subterranean energy stocks may have suffused and shaped the generations raised upon them, to consider how the combustion of coal and its hydrocarbon kin have fashioned the bodies, affects and passions of the fossil-fuel privileged (Yusoff, 2013, pp. 780-1). More than simply registering the extent of our practical reliance on non-renewable energy sources, it could be said that we have a developed `a deep love for the Carboniferous feedstock' (Yusoff, 2015, p. 209). For even before our lives begin, we are recipients of the corporeal generosities of ancient organisms: the lands which support us secured by hydrocarbon fuelled infrastructures, the couplings that spawned us sheltered by energy-intense architectures, our very cellular reproduction enabled by foods plumped with carbon-subsidized feedstocks, fertilizers and pesticides (Yusoff, 2015, p. 212).

Once impregnated by carbon-based life forms, the geologic body of the earth does not give up its energy-rich progeny lightly. Whole communities over many generations have taken on the task - or been tasked with - exhuming hydrocarbon deposits. Others have been expropriated, displaced, decimated to make way for extractive industries. Especially in the case of coal, communities forged around mining operations have evaded some of the modes of bodily discipline characteristic of modern institutions - while they have also been compelled to sustain and reproduce their corporeal being under conditions of extreme danger and hardship. While Timothy Mitchell explores the political possibilities attendant on the convening of labouring bodies around the strategic centres of coal extraction (2011, p. 18-27), it is D H Lawrence who reveals the visceral, affective relations that underpin mineworker solidarity:

... the miners worked underground as a sort of intimate community, they knew each other practically naked, and with curious close 
intimacy, and the darkness and the underground remoteness of the pit 'stall', and the continual presence of danger, made the physical, instinctive, and intuitional contact between them very powerful. This physical awareness and intimate togetherness was at its strongest down pit (cited in Curtis, 1997, p. 20).

The passage of warmth and light from one geological epoch to another, we might say, enabled by the passage of warmth and light from one labouring body to another. An intercorporeal chain we should add, that just over three decades ago, in the nation state from which we are writing, was intentionally and violently dismantled - dis-membered, dis-organized - in the face of fierce resistance (see Yusoff, 2015). By the same token, we need to be mindful of Andreas Malm's (2016) argument that the very ascent of fossilfuelled steam engines - in this same country some two centuries ago - was more than a matter of replacing insufficient or inconvenient energetic resources with a more potent, mobile and capacious energy source. Above all, Malm insists, steam power was power exercised over the burgeoning landless and disappropriated urban populace: the coalfired heat engine primarily a means of subordinating their unruly collective and reproductive potentiality to the self-augmenting circuits of capital accumulation (2016, pp. 124, 153-6).

Just as the creative energy of pyrotechnics was so often turned to the forging of shackles, armour, weapons - the apparatus of oppression and appropriation - so too were coalfuelled industrial engines set to the task of entrammelling a `superabundance of unemployed hands' (Malm, 2016, p.153). In these dynamics of capital accumulation, feminist theorists have repeatedly pointed out, there is a complicitous logic of control of labour power and of women's reproductive capacities - a pronounced link between specific regimes of production and particular sexual ethics (Mitropolous, 2012, pp. 106- 
8). Critical discourses on biopolitics have helped us to understand how the management - increasingly the self regulation - of sexual desire needs to be understood not only in terms of individuated bodies but through the more extensive realms of biological life (Parisi and Terranova, 2000). But as we have been suggesting, the thematic of fire combustion in all its forms - implicates organismic interests, affects, passions in a still more encompassing material-energetic field.

Connecting up the 'problem' of female desire to the abiding concerns of the high era of heat engines, Luciana Parisi and Tiziana Terranova note that entropy is that 'energy which cannot be reabsorbed back into the industrial social machine; it is energy which becomes a threat to the disciplinary order once it is pushed outside its walls' (2000: unpag.). Like the robust chambers built to contain the condensed, explosive energy of fossil carbon, the energy of the female body - with its risk of explosive discharge - has been seen to be in need of channelling into orderly (re)productive outlets. Strict geneaological continuity and filiative reproduction, that is, as the counterpart to evermore efficient and prodigious machines. In the bigger picture, overflowing energy presents a profound challenge not only to orthodox economistic thinkers and anxious ecologists, but to those forms of critical thought that cleave to notions of individuated, organismic being. For as Parisi and Terranova explain, 'female flows are not attributes of the organism and therefore of the woman's body. They are not defined by organization but by relations of matter and energy' (2000 unpag.). In the current fossil-fuelled world, the very matter and energy in question, we would add, is itself the expression of sexual and nonsexual reproduction - which is to say, the organismic desire of ancient plant life.

As we now know only too well, energy does indeed escape the heat engine's conversion of fuel to motive force: nineteenth century enthrallment with universal heat death rebounding as the current preoccupation with global climate change. But what is now 
pushing the earth system closer to irreversible change, what makes it so difficult to 'overcome' reliance on detrital carbon seems to be less the regulation of sexual desire as its hyperbolization. More so than even Bataille imagined, late twentieth and early twentyfirst century capitalism has found ways to cycle even the most gratuitous and voluptuary discharges back into the 'powder keg' of ceaseless accumulation. For Colebrook, the sensually and erotically charged interactions that constitute the intrinsic sexuality of the city have now reached unprecedented - and unmaintainable - levels of intensity. Furnished by mass industrialization and manifest as a kind of hyper-consumption, 'the global expansion of human desire' now weighs so heavily on the earth that it threatens geological catastrophe (2017, p. 56) 'This suggests that the city provides the condition for its own virtual destruction, and that it is essentially - like all sexual forces unsustainable', Colebrook concludes (2017, p. 54).

The contemporary contours and intensities of desire, in other words, take their force from sunlight sequestered during bygone epochs of the earth, and it is the very excess of 'geopower' fuelling these attractions and discharges that makes of sex itself a geologic force (see Yusoff et al, 2012). Playing this scenario through the lens of planetary fire, global climate change and the coming of the Anthropocene express more than just the logic of capital accumulation or patriarchal socio-sexual relations. If in ways that are diffuse and difficult to define, the current planetary predicament is also a matter of social, sexual, and political subjectification nourished by fossil hydrocarbons; an expression of overheated urges that channel the sexual chemistry of the Devonian, the Carboniferous, the Permian (Yusoff, 2015, p. 204).

Even more so than the pyrotechnic products that inflamed ancient passions, fossilnourished objects of desire play variations on the theme of earthly generativity that the earth itself never attempted, at intensities it cannot long endure - at least in its current 
state. To be sure, contemporary environmentalism grasps the unsustainability of the present order, though it tends to assume that reproductive discipline and a more measured filial inter-generationality provide the means to defuse and safely duct this (re)productive outburst - as if exuberance itself was a surpassable human aberrance rather than a planetary predilection. Agreeing that there is an urgent need to explore alternatives to certain of the sexual and energetic extravagances of the hydrocarbon era, our notion of thinking through the pyrosexual brings us back to the issue of our own inescapable implication in the 'fertility' of the earth and cosmos. The challenge of repositioning ourselves within the ancient, ongoing cross-fertilization of the organic and the inorganic, we suggest, raises profound questions, not only about what else we might make of our desires, but - inseparably - what else we could do with a planet of fire.

\section{Pyrosexual Futures}

For all its shortfalls, COP 21 - the 2015 UN Climate Change Conference - moves in the direction of an epochal shift in global usage of fossilized hydrocarbons. Ecological or environmental thought generally frames carbon descent in terms of a shift from the unilinear throughput of non-renewables to the cyclical flow of renewable energy. But in a closed circuit, or what Bataille referred to as a restricted economy, we more-or-less know what we are going to get in advance. In Bataillean terms, however, what we would be doing if we were to leave known reserves of fossil fuels in the ground is making a sacrifice. A sacrificial offering is a rupture in the cycle of exchange, a gesture without expectation of a return - and as such, an opening to an unknowable future. If decarbonization is the end of a tumultuous affair, so too is the turn to alternative energy sources an expression of desire, a reaching out to and cross-fertilization with vast and excessive powers, the summoning up 'of a new kind of life' (Grosz, 2008, p. 79). 
‘Fundamentally, no civilization on Earth can be anything but a solar society', exhorts energy theorist Vaclav Smil (1994, p. 157). To return more directly to solar radiation without the deep cushioning of fossil biomass - is also a kind of re-exposure. Our susceptibility to the forces of earth and cosmos is likely to be greatly exacerbated by coming transformations in the earth system triggered by carbon emissions and related anthropogenic 'forcings'. Already the density and distribution of terrestrial vegetation is shifting: we are seeing new rhythms, new intensities, in the dance of green fire and celestial fertility. If our earth will burn whatever we chose to do, so too, as we have seen, this a planet that burns more profusely when its climatic system is changing. We, the earth's first and foremost fire creature, will find ourselves not only impacted by this fire, but partaking in it. As we have done for a million years or more, we will fight fire with fire. Or perhaps, respond to fire's radiance and glory with exuberant fire play of our own.

But we privileged coal, oil and gas-fired peoples are arguably further from fire than we have ever been. Part of this privileging is to be ever more distant from the sweat, grime and danger of extraction, to have our entanglement with the fossil landscapes of the lithosphere at a safe remove. In contemporary machines, fire is an ever more sublimated spark, a fading referent that only flares figuratively in our Kindles, firewalls and flame wars. In the words of Hélène Cixous: ‘Formerly, I too sucked satiny coals. Once I burned my tongue. (That only happens if someone makes you lose faith.) Ever since I have no longer dared suck real fire; for a long time I lived on electricity' (1983, p. 24).

Our faith in fire has been cooling for some time. The fossil-fuelled heat engines of industrial modernity may have greatly advanced available force, but using fire to pump a piston, raise a hammer or turn a crank arm is also a diminution, a radical contraction of flame's polymorphic potential, a turning away from its power to play upon the 
metamorphic possibilities that inhere in matter (Clark and Yusoff, 2014, p. 22). Unable to compete with new industrial and electronic infrastructures, many kinds of artisanal fire are being quelled, the diverse and widespread fires of ceramicists, metallurgists, glassmakers - together with skills accrued over millennia - quietly extinguished (Clark, 2015). These endangered species of enclosed flame join a world of open fires - the broadcast burning of biomass by peasant and tribal peoples - that still struggle to survive the interdictions of fire prohibitionists.

The point is not simply to try and spool back human or earth history to reclaim earlier fire-sex couplings. The critical junctures of combustion and desire that we have alighted upon are intended, above all, to give a sense of what is possible, a feeling for the potentiality that at any moment vastly exceeds what is actually being done or made or tried out. If sex is indeed biological life's engine of difference, as Luce Irigaray, Elizabeth Grosz and many other feminist theorists have argued (see Grosz, 2011, pp. 102-3) - then fire, we have been arguing, is a preeminent means by which sexuality's differential force negotiates with the non-living world. While solar excess fuels sex and other forms of reproduction, it is the profligacy and creativity of organismic desire that fuels fire, and fire in turn that sparks and catalyses sexual life to new heights of generativity. However much combustion is currently implicated in the loss of life's richness - fossil-fuelled climate change, the clearing of rainforest for monocultural cropping - it is the restricted and injudicious application of fire that should be condemned. And fire itself, in collusion with sex, that must be preserved, enhanced, multiplied.

On a crowded, overheating planet, in a world in which desires have been stoked to hyper-consumptive intensities, there is a temptation is to turn to new strictures, tighter cyclings, tempered passions. Bataille's wager on glorious expenditure, we should recall, was a negotiation with earthly limits rather than their disavowal. Exuberant and 
gratuitous gestures are a way of living within limits, and it is important to remember that his hope for a non-explosive futurity lay, above all, in a multitude of small, intimate acts of generosity - warmth and light gifted between bodies. Or as we might put it in Grosz's terms, 'the sexualization of survival', where survival itself is but a fortuitous side effect of exploring and elaborating upon the play of the earth itself.

As Colebrook has argued, what currently threatens the survival of life on earth may be the very obsession with sustaining life (2012: 169). Life that is, not only in the guise of familial lineages and gene-lines - including the intergenerational continuities beloved of environmentalism - but in the more general sense of the enclosure or boundedness of the organic, and all the associated privileging of the living over the non-living (Colebrook, 2012: 171-2). To affirm the interplay of fire and sex, as we would have it, is to blaze a trail out of biologic or corporeal closure: to recognize a fertile - but also dangerous - implication of animal life with plant life, the living with the inorganic, the terrestrial with the astronomical. It is to kindle our kinship not only with fellow creatures, but with the 'anorganic' and incorporeal forces of earth and cosmos.

This is a matter not only imagining alternative 'environmental' futures, but of putting then into practice. Perhaps most difficult of all, we need to consider how fire and sex might collude in the construction of new architectures - in novel ways of organizing our socio-material lives. The question, that is of how 'play with minerals, fire, and colors' might contribute to the emergence of what Angela Mitropolous (2012, p. 229) refers to 'promiscuous infrastructures': the kind of experimental and improvised arrangements that are both enabled by and further promote generous collective existence. The opening up, the proliferation of pyrosexual futures that we are toying with requires a channeling of material possibilities into hopeful institutions and infrastructures; it depends upon a difficult and paradoxical play of limit and excess, purpose and gratuity, desire and 
renunciation. What might yet be done with fire, we suggest, resonates with Irigaray's sense of an elemental wonder that is in a vital interplay with sexual difference: her intuition of 'a primary passion and a perpetual crossroads between earth and sky, or hell, where it would be possible to rework the attraction between those who differ, especially sexually' (1993, p. 80).

\section{References}

Aitchison, L., 1960. A History of Metals, Vol. 1, London: MacDonald and Evans.

Alley, R., 2000. The Two-Mile Time Machine: Ice Cores, Abrupt Climate Change, and Our Future. Princeton: Princeton University Press.

Bataille, G., 2013. The economy equal to the universe. Scapegoat, 5, pp. 34-7.

Bataille, G., 1985. The solar anus. In A. Stoekl, ed. Georges Bataille, Visions of Excess: Selected Writings, 1927-1939. Minneapolis: University of Minnesota Press, pp. 5-9.

Bataille, G., 1986. Erotism: Death and Sensuality. San Francisco: City Lights.

Bataille, G., 1988. Inner Experience. New York: State University of New York Press.

Bataille, G., 1991. The Accursed Share, Vol. 1. New York: Zone. 
Bettini, G., 2014. Climate migration as an adaption strategy: de-securitizing climateinduced migration or making the unruly governable? Critical Studies on Security, 2(2) pp. 180-195.

Bowman, D., Balch, J., Artaxo, P. et al. 2009. Fire in the Earth system. Science, 324 (24 April), pp. $481-484$.

Bramwell, A., 1989. Ecology in the $20^{\text {th }}$ Century: A History. New Haven and London: Yale University Press.

Cixous, H., 1991. The Book of Promethea. Lincoln: University of Nebraska Press.

Clark, N., 2015. Fiery arts: pyrotechnology and the political aesthetics of the Anthropocene. GeoHumanities, 1(2), pp. 266-84.

Clark, N., 2017. Earth, fire, art: pyrotechnology and the crafting of the social. In N. Marres, M. Guggenheim, and A. Wilkie, eds, Inventing the Social. London: Mattering Press.

Clark, N. and Yusoff, K., 2014. Combustion and society: a fire-centred history of energy use, Theory, Culture \& Society, 31(5), pp. 203-26.

Colebrook, C., 2012. Sexual indifference. In T Cohen (ed.) Telemorphosis: Theory in the Era of Climate Change, Vol 1. Ann Arbor: Open Humanities Press, pp. 167-182

Colebrook, C., 2017. Sex and the (Anthropocene) city, Theory Culture \& Society, 34 (2-3), pp. 39-60. 
De Landa, M., 1997. A Thousand Years of Nonlinear History. New York: Swerve.

The Ecologist, 1972. A Blueprint for Survival. Harmondsworth: Penguin

Fernández-Galiano, L., 2000. Fire and Memory: On Architecture and Energy.

Cambridge, MA: MIT Press.

Freese, B., 2006. Coal: A Human History. Cambridge, MA: Arrow.

Grosz, E., 2008. Chaos, Territory, Art: Deleuze and the Framing of the Earth. Durham, NC:

Duke University Press.

Grosz, E., 2011. Becoming Undone: Darwinian Reflections on Life, Politics, and Art. Durham, NC and London: Duke University Press.

Goudsblom, J., 1992. Fire and Civilization, London: Penguin Press.

Haaland, R., 2007/8. Say it in iron: symbols of transformation and reproduction in the European Iron Age, Current Swedish Archaeology, 5/6, pp. 91-110.

Hazen, R.M. and J. M. Ferry 2010. Mineral evolution: Mineralogy in the fourth dimension. Elements 6(1), pp. 9-12.

Hird, M.. 2009. The Origins of Sociable Life: Evolution after Science Studies. Houndmills, Basingstoke: Palgrave Macmillan.

Irigaray, L., 1993. An Ethics of Sexual Difference. Ithaca, NY: Cornell University Press. 
Langton, M., 1998. Burning Questions: Emerging Environmental Issues for

Indigenous Peoples in Northern Australia. Darwin: Centre for Indigenous

Natural and Cultural Resource Management, Northern Territory University.

Curtis, T., 1997. Coal: An Anthology of Mining. Bridgend: Seren.

Malm, A., 2016. Fossil Capital: The Rise of Steam Power and the Roots of Global Warming.

London: Verso.

Marder, M., 2015. Pyropolitics: When the World is Ablaze. London and New York: Roman \& Littlefield.

Margulis, L. and Sagan, D., 1995. What is Life? New York: Simon \& Schuster.

Marx, K., 1973. Grundrisse. London: Penguin.

Mitchell, T., 2011. Carbon Democracy: Political Power in the Age of Oil. London: Verso.

Mitropolous, A., 2012. Contract and Contagion: from Biopolitics to Oikonomia.

Wivenhoe: Minor Compositions

Morgan, R., 1977. The wretched of the hearth, in R. Morgan, Going Too Far: The Personal Chronicle of a Feminist, New York: Random House.

Parisi, L. and Terranova, T., 2000. Heat-death: emergence and control in genetic engineering and artificial life' CTheory, 
https://journals.uvic.ca/index.php/ctheory/article/view/14604/5455

[last accessed 12 March 2017].

Pyne, S., 1994. Maintaining focus: an introduction to anthropogenic fire’ Chemosphere, 29 (5): 889-911.

Pyne, S., 1997a. Vestal Fire. Seattle: University of Washington Press.

Pyne, S., 1997b. World Fire: The Culture of Fire on Earth. Seattle: University of Washington Press.

Pyne, S., 2001. Fire: A Brief History. Seattle: University of Washington Press.

Pyne, S., 2015. The fire age, Aeon (5 May), http://aeon.co/magazine/science/how-our-pact-with-fire-made-us-what-we-are/ [last accessed 12 March 2017].

Raven, J. and Allen, J., 2003. Genomics and chloroplast evolution: What did cyanobacteria do for plants, Genome Biology, 4 (3) p. 209.

Rickards, L., 2013. Fire within, fire without, Fire Stories Symposium, Centre for the History of Emotions, University of Melbourne, 5 December, 2013.

Roberts, B., Thornton, C. and Pigott, V., 2009. The development of metallurgy in Eurasia, Antiquity, 83: pp.1012-1022. 
Sandilands, C., 1999. Sex at the limits. In É. Darier, ed. Discourses of the Environment. Oxford: Blackwell.

Scott, A., 2009. Forest fire in the global record. In A. Cerdà, and P. Robichaud, eds. Fire Effects on Soils and Restoration Strategies, Enfield, NH: Science Publishers, pp. 1-37.

Smil, V., 1994. Energy in World History. Boulder CO: Westview Press.

Smith, C.,1981. A Search for Structure: Selected Essays on Science, Art, and History. Cambridge, MA: MIT Press.

Vandiver, P., Soffer, O., Klima, B., and Svoboda, J., 1989. The Origins of Ceramic Technology at Dolni Věstonice, Czechoslovakia, Science, 246 (4933) pp.1002-8.

Wertime, T., 1973. Pyrotechnology: man's first industrial uses of fire, American Scientist, 61 (6), pp. 670-682.

Westbroek, P., 1983. Introduction: biological metal accumulation and biomineralization in a geological perspective. In P. Westbroek, and E. De Jong, eds, Biomineralization and Biological Metal Accumulation. Dordrecht, D. Reidel.

Worster, D., 1985. Nature's Economy: A History of Ecological Ideas. Cambridge: Cambridge University Press.

Wrangham, R., 2009. Catching Fire: How Cooking Made Us Human. London: Profile. 
Yusoff, K. et al ., 2012. Geopower: a panel on Elizabeth Grosz’s 'Chaos, Territory, Art:

Deleuze and the Framing of the Earth', Environment and Planning D: Society and Space, 30:

(6), pp. 971-88.

Yusoff, K., 2013. Geologic life: prehistory, climate, futures in the Anthropocene,

Environment and Planning D: Society and Space, 31: pp. 779 - 795.

Yusoff, K., (2015) Queer coal: genealogies in/of the blood, philoSOPHLA 5.2 (3), pp.

203-230.

\footnotetext{
${ }^{1}$ Pyrophytes are plants that have adapted to tolerate fire. There are two forms of pyrophytes, 'passive pyrophytes' which resist fire enough to survive when other plants are damaged and 'active pyrophytes' that contain volatile oils that 'encourage' or chemically incite fire. There are also pyrophile plants that require fire in order to complete their cycle of reproduction, often with the destruction of the "parent" plant as a consequence of the seeds progeny.

${ }^{2}$ Most closely associated with the work of evolutionary biologist Lynn Margulis, endosymbiotic theory - or symbiogenesis - posits that complex cells or 'eukaryotes' emerged through the coming together of formerly independent or 'free-living' microorganisms. For an extended discussion relating symbiogenesis to an expanded register of sexuality and non-sexual reproduction see Hird (2009), especially Ch. 3 and 5
} 